\title{
Особенности моделирования социальных отношений в публицистике Д.И. Фонвизина
}

\author{
Меринов В.Ю. \\ Белгородский государственный национальный исследовательский университет, \\ Россия, 308015, г. Белгород, ул. Победы, 85 \\ E-mail:merinov@bsu.edu.ru
}

\begin{abstract}
Аннотация. Автор полагает, что Фонвизин, искренне считавший себя человеком прогрессивных взглядов, оказался не готов к столкновению с европейской реальностью, переживающей один из периодов кризиса традиционалистской культуры и бурного становления новых социальных отношений, более свойственных уже следующему этапу развития Европы: индустриальному, урбанистическому и т.п. Анализ представленных в письмах из-за рубежа моделей социального поведения внутри хронотопов улицы, дома и театра позволил выявить его глубинные, мировоззренческие позиции. Суть этих позиций состоит в том, что основой социального порядка русский сатирик считал четкое сословное разделение, исполнение каждым человеком своей сословно-социальной роли, свойственной для традиционалистского типа культуры. Трансформацию моделей социального поведения, нарушения и ослабление границ между социальными группами он воспринял как предвестники крушения моральных основ современного ему общества.
\end{abstract}

Ключевые слова: Фонвизин, Просвещение, русская публицистика XVIII века, модели социального поведения, публицистический хронотоп, моральная деградация

Для цитирования: Меринов В.Ю. 2021. Особенности моделирования социальных отношений в публицистике Д.И. Фонвизина. Вопросы журналистики, педагогики, языкознания, 40 (4): 431-441. DOI: $10.52575 / 2712-7451-2021-40-4-431-441$

\section{Features of Modeling Social Relations in Publicism D.I. Fonvisina}

\author{
Valery Y. Merinov \\ Belgorod National Research University \\ 85 Pobeda St, Belgorod 308015, Russian Federation \\ E-mail:merinov@bsu.edu.ru
}

\begin{abstract}
Abstarct. The author believes that Fonvizin, who sincerely considered himself a man of progressive views, was not ready for a collision with European reality, which is going through one of the periods of the crisis of traditionalist culture and the rapid formation of new social relations, more characteristic of the next stage of European development: industrial, urban, etc. Analysis of the models of social behavior presented in letters from abroad within the chronotopes of the street, house and theater made it possible to reveal his deep, worldview positions. The essence of these positions is that the Russian satirist considered the basis of the social order to be a clear class division, the performance by each person of his class-social role, characteristic of the traditionalist type of culture. He perceived the transformation of models of social behavior, violations and weakening of boundaries between social groups as harbingers of the collapse of the moral foundations of contemporary society.
\end{abstract}

Key words: Fonvizin, Enlightenment, Russian journalism of the 18th century, models social of behavior. publicistic chronotope, moral degradation.

For citation: Merinov V.Y. 2021. Features of Modeling Social Relations in Publicism D.I. Fonvisina. Issues in Journalism, Education, Linguistics, 40 (4): 431-441 (in Russian). DOI: 10.52575/2712-74512021-40-4-431-441 
Правота... не допускает поселиться в его [государя] голову несчастной и нелепой мысли, будто бог создал миллионы людей для ста человек.

Д.И. Фонвизин.

Рассуждение о непременных государственных законах

Беспримерной его щедрости едва ли можно найти подражателей. Из девяти тысяч душ крестьян, пожалованных ему императрицею, он подарил четыре тысячи трем секретарям, кои находились при нем по иностранным делам.

Д.И. Фонвизин. Жизнь графа Никиты Ивановича Панина

\section{Введение}

Д.И. Фонвизин - один самых популярных и узнаваемых русских драматурговсатириков. Кроме драматургии, Фонвизин известен своими переводами иностранной публицистики, собственным творчеством на социальную тематику, а также письмами, имеющими более широкий круг распространения, «...нежели семейный и дружеский...» [Степанов, 1986, с. 220]. Публицистичность - важнейшая черта творчества Д.И. Фонвизина. Собственно, жанры (включая сатирические, с их «обличительно-проповедническим характером ...» [Горнфельд, 1890-1907, с. 331]), выбираемые им для публичного высказывания, предполагают постановку острых животрепещущих социальных проблем, активную социальную позицию автора, отстаивание собственных социально-политических идеалов и ценностей.

В истории литературы и публицистики фигура Фонвизина вызывает споры. С одной стороны, автор «Недоросля» виделся носителем идеалов свободы и гуманизма. А.С. Пушкин в «Евгении Онегине» отзывался о нем так: «Сатиры смелый властелин / ...друг свободы», упоминая о Фонвизине в этом же контексте и в других своих сочинениях [Томашевский, 1990, с. 62], а В.Г. Белинский в «страшной картине французского общества», созданной в письмах драматурга, увидел «начало Французской революции» [Белинский, 1956, с. 205]. Эта же линия была продолжена и доведена практически до своего предела в советском литературоведении. Такие авторитетные авторы, как П.Н. Берков [1947], Д.Д. Благой [1960], Г.А. Гуковский [1947; 1999], Н.В. Коршунова [2005], Л.И. Кулакова [1966], Г.М. Макогоненко [1969], К.В. Пигарев [1954] настаивали на едва ли не революционном характере творчества Фонвизина. Так, Г.М. Макогоненко полагал, что «...обличая уродства социальной жизни... и показав истинное лицо российского помещика... [Фонвизин] продолжил эту борьбу дворянских просветителей с идеологией крепостников...» [Макогоненко, 1969, с. 229].

Вместе с тем параллельно приведенной позиции существовала точка зрения, оценивающая вклад Фонвизина в революционное движение, скажем так, более сдержанно. Среди авторов, отстаивающих ее, в XIX столетии выделяется фигура исследователя литературы и поэта П.А. Вяземского, создателя историко-биографического труда «ФонВизин». Отмечая определенные противоречия между произведениями, созданными им в России и в Европе, он писал: «Дома бич предрассудков, ревнитель образованности и успехов разума, Фон-Визин путешественник смотрит на все глазами предрассудка и только что не гласным образом, а отрицательными умствованиями, проповедует выгоду невежества» [Вяземский, 1848]. В какой-то степени в XX в. советский публицист и критик 
С.Б. Рассадин [1980; 1985; 2001; 2008] продолжил рассматривать творчество Фонвизина под этим же углом зрения, считая, что политические взгляды сатирика сочетали консервативные и передовые идеи. В 1999 году А. Зорин заявил, что «мера оппозиционности, скажем Фонвизина... оказывается существенно преувеличена» [Зорин, 1999, с. 10]. В.И. Моряков высказался еще более определенно, в каком-то смысле переводя разговор с языка идейного на социально-философский: «Неприятие Фонвизиным нарождавшегося во Франции буржуазного общества свидетельствует, на наш взгляд, что западноевропейская концепция личности как свободного субъекта сознательной волевой деятельности не стала основой его убеждений. Он еще... в значительной степени был подчинен по большей части архаичному российскому социуму, отождествлен со своей социальной ролью» [Моряков, 2011, с. 65].

Творчество Фонвизина пришлось на период колоссального слома в западной цивилизации традиционалистского типа культуры. Нединамичное, аграрное, пассивнопотребительское, корпоративно-коллективистское, религиозное, иерархическое (ориентированное на вертикальные социальные связи), «закрытое» (К. Поппер) «сословноклассовое» (В.П. Илюшечкин), «эгалитарное, ранжированное и стратифицированное»» (М. Фрид) общество трансформировалось в общество современного («открытого» (К. Поппер), «рационального» (М. Вебер) «техногенного» (В.С. Степин), «городского» (М.С. Каган)) типа (урбанистическое, индустриальное, политическое, активистское, самоорганизующееся, личностно ориентированное и т.п.).

Конечно, процесс этот нелинейный, сложный, неоднородный занимает не одно столетие и продолжается по сей день. Демократические революции второй половины XVIII в. в Северной Америке и Франции продемонстрировали проективную способность граждан самим формировать новые политические институты, изменять контуры властных отношений. Однако сами революции, как правило, только юридически и политически закрепляют те новые социальные отношения, нормы, правила социального поведения и т.п., которые складываются и накапливаются постепенно, десятилетиями и столетиями. Об этом, собственно, идея К. Маркса об исторических формациях, основное внимание в которой оказалось уделено проблеме трансформации одной формации в другую. Маркс, не единожды говоря о революции как «локомотиве истории», все же вполне справедливо указывал на то, что процесс перехода имеет длительный плавный эволюционный характер. Маркс подчеркивал то, что новые отношения различного типа (конечно, в первую очередь, «производственные» и «отношения собственности», но и, учитывая взаимосвязанность общественных процессов, финансовые, социальные и др., а также изменения идеологических и мировоззренческих основ общества - «надстройки») исподволь меняют прежнюю роль классов, отдельных слоев населения, групп, как бы «прорастают» сквозь старую, изживающую себя «общественно-экономическую формацию» и служат главными движущими «производительными» силами истории [Маркс, 1959, с. 7].

Именно эти перемены в социальном поведении людей в XVIII- XIX вв., воспринимаемые в том числе в своем конфликтном измерении (у Маркса как «борьба антагонистических классов»), в первую очередь беспокоили и заставляли размышлять европейских интеллектуалов. Особенно сложно было выявлять причины и последствия происходящих перемен выходцам из тех культур, которые находились на периферии мировых культурных тенденций. С одной стороны, новые отношения, модели поведения бросались им в глаза, сказывалась разница культур, с другой - они не слишком соответствовали идеальным представлениям о Порядке, пусть даже и новом. Несмотря на знакомство с передовыми гуманистическими идеями и даже на декларативном уровне разделяя их, они оставались преимущественно в пространстве социальных представлений и норм архаической, традиционалистской культуры, в рамках которой, к примеру, крестьянин являлся лишь «элементом земельной собственности» [Майданский, 2008, с. 151]. К тому же нельзя от- 
рицать и групповые (классовые - К. Маркс) интересы, в той или иной степени влиявшие на восприятие и оценку этих новых явлений.

Социально-политические взгляды Фонвизина как в драмах, так и в письмах из-за рубежа наиболее наглядно раскрываются в конструировании им социальных отношений внутри локальных хронотопов (от др. гр. Chronos - время и topos - место, пространство, «время-пространство»). «Всякое вступление в сферу смыслов, - писал М.М. Бахтин, свершается только через ворота хронотопов» [Бахтин, 2000, с. 56]. Как правило, в записках путешественника (письмах-отчетах о путешествии) хронотоп занимает крайне важное место. Причем в хронотоп фонвизинских писем входит не только «хронотоп дороги, гостиной, замка», о которых говорил М. Бахтин, собственно и формирующий жанровую специфику, но и территориально локализованные хронотопы города, городской улицы, аристократического дома, театра, дающие представление о стране, в целом. Именно зафиксированные автором особенности социального поведения в этих хронотопах, по нашему мнению, в наибольшей мере передают отношение автора к новым явлениям культуры. Рассмотрим три из них: это хронотопы городской улицы, дома и театрального пространства.

\section{Городская улица}

Нужно сказать, что основное внимание Фонвизина приковано к городскому пространству, что, конечно, неслучайно. Французская городская улица - одно из наиболее впечатливших Фонвизина социальных пространств. Именно в городе проходящие изменения явлены в своем наиболее публичном, заметном даже для стороннего наблюдателя виде. В определенном смысле именно улица становится катализатором культурных изменений, распространяющихся и на другие социальные пространства. Похоже, что для Фонвизина улица стала местом и символом грандиозной эпической битвы, развернувшейся между третьим сословием (горожанами) и аристократией. Сам тон посланий не оставляет сомнений в том, что русский путешественник считает, что эта битва аристократами уже фактически проиграна или, во всяком случае, очень близка к их безоговорочному поражению, что в системе ценностей Фонвизина равно катастрофе и моральной деградации общества.

Так, по мнению Фонвизина, городская улица концентрирует в себе худшие качества современного западного общества, одновременно являющиеся характерными признаками Франции и общества французского как европейского культурного лидера. Так, заметными (физически, на уровне обоняния) индикаторами общественного регресса становятся грязь и запах нечистот, на которые автор писем чрезвычайно концентрируется и постоянно обращает внимание, так что для читателя они становится чуть ли не визитной карточкой Франции: «...въехали мы во Францию. Первый город Ландо, крепость знатная. При въезде в город ошибла нас мерзкая вонь, так что мы не могли уже никак усомниться, что приехали во Францию. Словом, о чистоте не имеют здесь нигде ниже понятия, и кто не хочет задохнуться, тот, конечно, окна не отворяет. <..> Потом приехали мы в Бресс... коего жители также по уши в нечистоте...», «...надлежит зажать нос, въезжая в Лион, точно так же как и во всякий французский город» [Фонвизин, 1959, с. 420]. Запах закрепляется за французами, как и неприятный запах за еврейскими местечками, - еще один постоянный спутник путешественника. Между тем для Фонвизина важно заявить, что проблема имеет рукотворный характер и указать на виновника этой антисанитарии. Это простые горожане. Именно они превращают город в пространство социального беспорядка, разрушенной иерархии, «изволят лить» помои прямо «...из окон на улицу», там же «господа французы обжигают свинью» [Фонвизин, 1959, с. 420]. Причиной такого девиантного поведения является безнаказанность горожан. Горожане не слишком опасаются властей, они ведут себя на улицах совершенно бесцеремонно, как единственные их хозяева, так, как будто эта территория принадлежит исключительно им, а не является территорией, над которой должны властвовать и контролировать те, кому это полагается по праву рождения и их социальному статусу, то есть высшие круги и полиция, представляющая со- 
словное государство. Французская полиция бездействует («...пустила бы наша полиция среди Миллионной улицы опаливать свинью!» [Фонвизин, 1959, с. 420], а ведь ею так «хвалятся французы» (автор иронизирует над предметом гордости французов). Бессилие сословной власти, неспособность ее навести в городах порядок, исправить возмутительные социальные практики, произвол третьего сословия являются для Фонвизина первым симптомом общественного неблагополучия. Подобный же стиль поведения отмечается автором и в других городских хронотопах. Так, физическая нечистоплотность города становится прелюдией и символом всеобщей моральной распущенности и упадка, также неустанно изобличаемыми автором «Недоросля».

Одним из значимых для Фонвизина событий, оставившим у него двойственное чувство, и, в определенном смысле, поставившее автора писем в тупик, становится чествование юбилея Вольтера. Часть этого действа разворачивается именно на улице. В этот день улица оказывается в буквальном смысле захваченной третьесословной толпой, не встречая ни малейшего сопротивления или хоть какого-нибудь контроля со стороны власти. Горожане при этом невероятно активны, для их описания, как правило, применяются глаголы интенсивного физического действия. Они сами пишут сценарий встречи, определяют правила поведения участников и расставляют политические акценты: «народ закричал: «des flambeax, des flambeax!» (Факелов, факелов! (франц.)) ...велели кучеру ехать шагом, и бесчисленное множество народа с факелами провожало его до самого дома, крича непрестанно: «Vive Voltaire!» (Да здравствует Вольтер! (франц.))» [Фонвизин, 1959, c. 442]. Горожане, не стесняясь, говорят от имени всей Франции: «Прими, Вольтер, венок, который тебе дарят; прекрасно заслужить его, когда Франция тебе его преподносит». По сути, они устанавливают альтернативную социальную иерархию, проявляя тем самым свою социально-политическую субъектность. Вольтер становится моральным и социальным центром, его встречают как нового мессию, несут на руках, а Фонвизин сравнивает горожан с религиозной сектой.

В формировании этой новой альтернативной социально-властной реальности активно участвуют лидеры общественного мнения - великие французские просветители, философы-энциклопедисты - Жан Лерон Д'Аламбер (член Парижской академии наук, Французской Академии, Лондонского королевского общества, Петербургской академии и многих других академий) и Дени Дидро (писатель, драматург, создатель многотомника «Энциклопедия, или Толковый словарь наук, искусств и ремёсел», иностранный почётный член Петербургской академии наук и т.д.). Об этом с нескрываемой тревогой пишет Фонвизин. В свете идей Просвещения, как живые носители концепций социальной справедливости, равенства, законности, политической гражданственности, защитники простых людей и т.д., они вполне закономерно связываются Фонвизиным с улицей, представлены как ее органическая часть. При этом проявления новых стратегий социального поведения, свидетелем которых стал русский сатирик, настолько пугают его, что он видит в этом, как правило, одни негативные стороны. Величайшие социальные мыслители, оставившие свой след в истории мировой политической мысли и социальных движений, авторы «Великой Французской энциклопедии» упоминаются в крайне уничижительном контексте, во множественном числе («Д'Аламберты, Дидероты...») и разоблачаются как «уличные шарлатаны» и даже «...хуже их...»: «... - в своем роде такие же шарлатаны, каких видел я всякий день на бульваре; все они народ обманывают за деньги, и разница между шарлатаном и философом только та, что последний к сребролюбию присоединяет беспримерное тщеславие...» [Фонвизин, 1959, с. 481]. Не гнушается русский автор и, ради дискредитации их образа, использовать и довольно спорные портретные характеристики: «...Из всех ученых удивил меня Д'Аламберт. Я воображал лицо важное, почтенное, а нашел премизерную фигуру и преподленькую физиономию» [Фонвизин, 1959, с. 448]. Сама улица предстает как сборище шарлатанов, дураков и другого праздного люда: «...народ... весьма скотино- 
ват... куча людей, а по средине шарлатана... смешит дураков шутками... словом народ праздный и зазевывается охотно, а притом весьма грубый» [Фонвизин, 1959, с. 428].

Фонвизин фиксирует и вопиющие отступления от социальных норм и иерархии самими верхами. Так, к примеру, офицер в нарушение сословного этикета «...шатается без слуги» [Фонвизин, 1959, с. 429]. Принц крови ведет себя как простой человек, говорит «...грубо, произнося слова отрывисто», ходит «...переваливаясь, разинув рот, не смотря ни на кого», толкает «...всякого, с кем встретится», смеется «...без малейшей причины, сколько сил есть громче» [Фонвизин, 1959, с. 483]. Пример элиты заразителен для других представителей элиты: «...все молодые люди подражают его [принца] тону...» [Фонвизин, 1959, с. 483].

Под водительством по сути самозванцев и брошенные на произвол судьбы властями, забывшими свой сословный долг и принципы (этические и поведенческие), города и улицы сдаются охлосу, превращаются в пространство праздности и нравственной деградации: «Развращение нравов дошло до той степени, что подлый поступок не наказывается уже и презрением. Честнейшие действительно люди не имеют нимало твердости отличить бездельника от доброго человека», «...деньги есть первое блаженство здешней земли... Божество его - деньги. Из денег нет труда, которого б не поднял, и нет подлости, которой бы не сделал» [Фонвизин, 1959, с. 481].

\section{Театр}

Театр становится одним из главных символов этого драматического превращения. Он фактически сливается с улицей, предстает как общее пространство безответственности и лени: «И действительно, всякий день здесь праздник. Видя с утра до ночи бесчисленное множество людей в беспрерывной праздности, удивиться надобно, когда что здесь делается. <..> Все столько любят забавы, сколько труды ненавидят; а особливо черной работы народ терпеть не может... Не упоминая о садах, всякий день пять театров наполнены» [Фонвизин, 1959, с. 475].

Границы между улицей и театром, как и между улицей и домом весьма условны. Народ - символ улицы - размыкает герметичность социальных миров (к примеру, Французской академии). Горожане стирают границы между улицей и не улицей. В сцене чествования Вольтера горожане «с непрестанными восклицаниями» препровождают его в Академию (там писателя и драматурга выбирают во временные директора) и в театр, соединяя пространства улицы и публичного заведения. В театре уличная публика, разрывая границы между партером и сценой, отменяя заранее подготовленный сценарий (нарушая театральную субординацию), присваивает себе право определять повестку событий. Так же, как и на улице, партер активно одобряет происходящее «громким рукоплесканием, продолжавшимся близ четверти часа», аплодирует «с великим криком» и при этом «велит» актерам повторить чтение стихов. Дальнейшие события только способствуют нарастанию тревожности русского путешественника. В театре автором посланий фиксируется опасная, по его мнению, субъектность третьего сословия. Так, публика оказывает Вольтеру знаки почета и уважения, скорее достойные правящего и отмеченного славой монарха (бюст, лавровый венок), нежели простого писателя. Фонвизин с явным беспокойством отмечает, как условная жизнь сцены сливается с реальной жизнью улицы. Условность и театральность действа в определенной степени снимается выходом процессии на улицу, что переводит эту ситуацию в гораздо более серьезный социальный регистр.

Тот же партер включает в поле своего зрения и в зону своей эмоциональности ложу, поступки представителей высших сословных групп, громко аплодируя не только нарушителю сословных правил дюку дэ Бурбону, посмевшему вызвать на дуэль принца крови, но и самому принцу, не побоявшемуся повести себя храбро и ответить за свою оплошность. Вертикальные границы между социальным верхом и низом предстают как слабые. Конечно, сохраняется формальная граница (пространственная между партером и 
балконом), но она становится проницаемой для публичного высказывания, проявления эмоций. Сквозь нее проникают шум, аплодисменты, крики, вовлекающие жизнь верхов в публичное открытое пространство, демократизируя пространство театра («...публика, сведав, что они дрались, обернулась к их ложе и аплодировала им с несказанным восхищением, крича: браво, браво, достойная кровь Бурбона!» [Фонвизин, 1959, с. 440]).

Театральная ложа еще, по крайней мере раз, становится пространством нарушения норм и разложения в случае, когда она «...наполнена была лучшими людьми города», а приставленный часовой, «...соскучив стоять на своем месте, отошел от дверей, взял стул и, поставя его рядом со всеми сидящими знатными особами, сел тут же смотреть комедию, держа в руках свое ружье» [Фонвизин, 1959, с. 488]. Позиция автора очевидна: хотя бы в ложе, как в элитарном пространстве, должны соблюдаться сословные порядки. Отсюда вполне объяснимая реакция: «Удивила меня дерзость солдата...» [Фонвизин, 1959, с. 488]. Однако еще больше удивляет русского писателя полное отсутствие, как ему кажется, должной реакции со стороны правящего класса: «Подле него сидел майор его полка и кавалер св. Людовика. Удивила меня дерзость солдата и молчание его командира, которого взял я вольность спросить: для чего часовой так к нему присоседился? "C'est qu'il est curieux de voir la comedie" [Потому, что ему любопытно смотреть комедию (франц)], - отвечал он с таким видом, что ничего странного тут и не примечает» [Фонвизин, 1959, с. 488].

Другая сцена в театре, переходящая на улицу, описанная в письмах Фонвизина, становится еще более ярким свидетельством проявления субъектности и солидарности горожан, а также их способности противостоять действиям сословной власти. В этом случае происходит прямое столкновение правящей и подвластной социальных групп. Пространство театра оказалось слепком социального пространства, разделенного на зоны социального престижа и влияния (партер и ложа). Партер претендует на большую роль в распределении социального влияния. При этом он дискредитируется со стороны ложи, куда, собственно, перебирается сам автор, как пространство Хаоса: «бешенства», «бунта», «нахальства», насилия и запугивания («насильство партера... грозили все вверх дном поставить» [Фонвизин, 1959, с. 435]). Здесь «принуждают», правят низкие чувства - безнаказанность, хамство, невоздержанность, бескультурье («этакого крика в наших кулачных боях, я чаю, не бывало... Какой поднялся визг от дам!» [Фонвизин, 1959, с. 435]).

В ответ на требование партера, трактуемое как безумное упрямство и наглое притязание («...Кричали, что они не выйдут из партера, не видав требуемого танца» [там же]), власть рассердившись, проявляя твердость, и решив «не потворствовать нахальству партера», прибегает к арестам и насилию в отношении: «...остервенелого народа... вбежали гренадеры... Самых задорных стали хватать за ворот и отсылать в городскую тюрьму» [Фонвизин, 1959, с. 436]. Упорядочивание хаотического пространства социального низа приходит извне и сверху. Быстро и решительно, к явному удовольствию Фонвизина, в театре наводится порядок с помощью вооруженного караула («...по повелению графа, вбежали в партер человек с пятнадцать гренадер с обнаженными палашами и закричали, чтоб в один момент все шли из партера или рубить будут» [Фонвизин, 1959, с. 435], так смятение против правительства и бунт закончились [Фонвизин, 1959, с. 435]. Не скрывает Фонвизин и злорадство по поводу поражения горожан: «Вся храбрая сволочь, которая за минуту пред тем грозила театр поставить вверх ногами, бежала сломя голову вон: один давил другого и в четверть часа все выбежали вон, чем дело и закончилось» [Фонвизин, 1959, с. 435].

Между тем, проиграв сражение, народ не собирался сдаваться, что явилось полной неожиданностью для русского сатирика. «Боевые действия» перенеслись на улицу. Здесь Фонвизин столкнулся с маловлиятельным в традиционном обществе феноменом - феноменом демократического потребителя. Ключом к народной победе становятся деньги или потерянная театром прибыль, ставшая действенным рычагом демократического влияния в формирующемся обществе нового типа. Горожане, проявляя недюжинные навыки граж- 
данской солидарности, объявляют бойкот театру, вынуждая его директора «со слезами» просить власти остановить войну против народа, приносящего основную прибыль. Финал этой драмы оставляет Фонвизина в некоторой растерянности: «не знаю, что-то будет сегодня» [Фонвизин, 1959, с. 436].

\section{Дом}

Признаки упадка особенно бросаются в глаза в последнем бастионе сословного общества - французском аристократическом доме. Среди таковых Фонвизин выделяет «невежливостное» поведение слуг. Так лакеи не считают нужным вставать и снимать шляпы перед представителями высшего: «...Лакеи здешние такие неучи, что в самых лучших домах быв впущены в переднюю, кто бы не прошел мимо, дама или мужчина, ниже с места не тронутся и, сидя, не снимают шляп...», «с крайней неучтивостью» ведут себя даже с представляющим «королевскую особу», проходящим «мимо этих скотов...» [Фонвизин, 1959, с. 429]. Другие слуги, по мнению Фонвизина, также нарушают сословный этикет. Они не спешат выполнять неоплаченную и, вероятно, не обговоренную в договоре работу. Работники выдвигают свои требования и ограничения, тем самым как бы, разрывая общую волю правящей группы, в отношении нижестоящих по социальной лестнице: «... а слуги их... надвинув на глаза шляпу, кроме своего господина не смотрят ни на кого... Буде же нет лакея, то несчастный хоть умри с голоду... А соседа твоего лакей, как ни проси, тарелки твоей не примет: je ne sers que mon maître [кроме своего господина, я никому не служу]», «...услуга за столом очень дурна. Я, когда в гостях обедаю (ибо никогда не ужинаю), принужден обыкновенно вставать голодный», «...кавалеры святого Людовика, люди заслуженные... ходят с тарелкою около сидящих и просят, чтоб кушанье на тарелку им положили. Как скоро съест, то побежит в переднюю к поставленному для мытья посуды корыту, сам, бедный, тарелку свою вымоет...» [Фонвизин, 1959, с. 430]. Образцом «правильного» социального поведения служат русские крепостные, готовые услужить любому представителю элиты: «Фишер и Петрушка одеты у меня в ливрее и за столом служат. Я предпочитаю их двум нанятым французам, которых нельзя и уговорить, чтоб, кроме меня, приняли у кого-нибудь тарелку» [Фонвизин, 1959, с. 430].

Вся домашняя жизнь французской аристократии, включая и поведение, представляется Фонвизину напрочь лишенной сословного достоинства. Так, маркиза Fraigeville, нарушая сословные принципы, «...изволит обедать на поварне против очага», то есть там, где едят слуги [Фонвизин, 1959, с. 432]. Причиной такого, по мнению автора, падения нравов является не только бедность французского высшего сословия, но прежде всего потеря стыда, непонимание значимости своего социального положения в структуре сословного общества: «Она без всякого стыда отвечала мне, что как нет у нее за столом людей посторонних, то для экономии, чтоб не разводить огня в камине столовой комнаты, обедает она на поварне, где на очаге огонь уже разведен. Жаловалась мне, что дрова очень дороги и что она одною поварнею чувствительный убыток терпит» [Фонвизин, 1959, с. 432].

Бедность элиты, вынужденная экономия на мелочах вызывают лишь высокомерные замечания небогатого по меркам своего отечества русского путешественника о преимуществах жизни помещиков в крепостной России: «Спрашивал я, для чего вина и воды не ставят перед кувертами? Отвечали мне, что и это для экономии: ибо-де примечено, что коли бутылку поставить на стол, то один всю ее за столом выпьет, а коли не поставить, то бутылка на пять персон становится. Подумай же, друг мой, из какой безделицы делается экономия: здесь самое лучшее столовое вино бутылка стоит шесть копеек, а какое мы у нас пьем - четыре копейки. Со всем тем для сей экономии не ставят вина в самых знатнейших домах. Клянусь тебе, по чести моей, что как ты живешь своим домиком, то есть как ты пьешь и ешь, так здесь живут первые люди; а твоего достатка люди рады б к тебе в слуги пойти. Отчего же это происходит? < ..> видя на мне соболий сюртук, на который я полошил золотые петли и кисти. Всякий француз подходит ко мне и, поглядя на обшлаг, 
вне себя бывает от восхищения... Перстень мой, который вы знаете и которого лучше бывают часто у нашей гвардии унтер-офицеров, здесь в превеликой славе. Здесь бриллианты только на дамах, а перстеньки носят маленькие», «не понимаю. У нас все дороже; лучшее имеем отсюда втридорога, а живем в тысячу раз лучше. Если б ты здесь жила так, как в Москве живешь, то б тебя почли презнатною и пребогатою особою <..> Смешно вздумать, каких здесь обо мне мыслей и по тому одному, что у меня в камине огонь не переводится. II a une fortune immense! C'est un senateur do Russie! Quel grand seigneur! [У него громадное состояние! Это русский сенатор! Большой вельможа! (франц.)]» [Фонвизин, 1959 , c. 432].

В круг зрения путешественника попадает и белье (столовое и нательное): «Белье столовое во всей Франции так мерзко, что у знатных праздничное несравненно хуже того, которое у нас в бедных домах в будни подается. Оно так толсто и так скверно вымыто, что гадко рот утереть. Я не мог не изъявить моего удивления о том, что за таким хорошим столом вижу такое скверное белье. На сие в извинение сказывают мне, que cela ne se mange pas [это не едят (франц.)] и что для того нет нужды быть белью хорошему», «Какое белье! Боже! Ты видишь, чем мы принуждены утираться! Подумай, друг мой, что, кроме толстоты салфеток, дыры на них зашиты голубыми нитками!», «Я остолбенел, увидя, какие на них рубашки! Не утерпел я, чтоб не спросить их: для чего к такой дерюге пришивают они тонкие прекрасные кружева? На сие, в извинение, сказали мне, que cela ne se voit pas [этого не видно снаружи (франц.)]» [Фонвизин, 1959, с. 430].

Довершает картину разложения французской знати их готовность пойти в услужение (то есть, работать) к русским аристократам: «...каждый французский дворянин, при всей своей глупой гордости, почтет за великое себе счастие быть принятым гувернером к сыну нашего знатного господина... Множество из них мучили меня неотступными просьбами достать им такие места в России» [Фонвизин, 1959, с. 484].

\section{Заключение}

Подведем краткий итог. Мы полагаем, что в письмах Фонвизина отразились двойственность и расколотость мироощущения русского дворянина-интеллигента XVIII столетия. C одной стороны, будучи приверженцем просвещенческой идеологии, пусть в ее усеченном и неразвитом виде, он не мог не ратовать за гуманизацию социальных порядков в России, а с другой - реальные образцы поведения (социальные роли), вероятно, сталкивались в его сознании с их идеальными моделями, взятыми из социальных практик крепостнического государства и традиционалистской культуры, в рамках которой каждый человек должен был строго соответствовать своей закрепленной от рождения сословно-социальной роли, своему социальному статусу, месту в социальной иерархии. Эти принципы должны были распространятся как на подчиненных, так и на властителей. Будучи во Франции, русский сатирик увидел, что нарушения социального порядка, как его понимал Фонвизин, идут с обеих сторон, переводя «нарушителей» из «человеческого» в «скотское» состояние.

\section{Список литературы}

1. Бахтин М.М. 2000. Формы времени и хронотопа в романе: очерки по исторической поэтике. В кн.: Бахтин М.М. Литературно-критические статьи. М., Художественная литература, $121-290$.

2. Белинский В.Г. Письма: 1829-1840. 1956. Т. 11. Под ред. Н.Ф. Бельчикова. Полное собрание сочинений. В 13 т. М., Изд-во Акад. наук СССР, 718 с.

3. Берков П.Н. 1947. Театр Фонвизина и русская культура. В кн.: Русские классики и театр. Под ред. Е. Кузнецова. М.-Л., Искусство: 7-108.

4. Благой Д.Д. 1960. История русской литературы XVIII века. Под ред. Д.Л. Устюжанина. М., Учпедгиз, 582 с. 
5. Вяземский П.А. 1848. Фон-Визин. Санкт-Петербург, тип. Деп. внеш. торг., 468 с.

6. Гуковский Г.А. 1947. Фонвизин. В кн.: Литература XVIII века. T. IV. История русской литературы. В 10 т. М.-Л., Изд-во АН СССР: 152-200.

7. Гуковский Г.А. 1999. Русская литература XVIII века. М., Аспект Пресс, 453 с.

8. Горнфельд С.В. 1890-1907. Энциклопедический словарь Брокгауза и Ефрона. В 86 т. (82 т. и 4 доп.). СПб.

9. Зорин А. 1999. Григорий Александрович Гуковский и его книга. В кн.: Гуковский Г.А. Русская литература XVIII век. М., Аспект Пресс: 3-11.

10. Коршунова Н.В. 2005. Фонвизин. В кн.: Общественно-политическая мысль России XVIII - начала XX века. Энциклопедия. Под ред. В.В. Журавлева. М., Политическая энциклопедия (РОССПЭН), 583-584.

11. Кулакова Л.И. 1966. Денис Иванович Фонвизин. Л., Просвещение, 177 с. $146-169$.

12. Майданский А.Д. 2008. Логика и феноменология всемирной истории. $\Sigma \mathrm{N}$ АРХН, 5 :

13. Макогоненко Г.М. 1969. От Фонвизина до Пушкина. Из истории русского реализма. М., Художественная литература, 498 с.

14. Маркс К. 1959. К критике политической экономии. В кн.: К. Маркс, Ф. Энгельс. Собр. соч. Изд. 2-е. Т. 13. М., Политиздат, 771 с.

15. Моряков В.И. 2011. Д.И. Фонвизин о Франции последней трети XVIII в. Вестник Московского университета. Серия 8: История, 3: 52-68.

16. Пигарев К.В. 1954. Творчество Фонвизина. М., Изд-во АН СССР, 314 с.

17. Рассадин С.Б. 1980. Фонвизин. М., Искусство, 288 с.

18. Рассадин С.Б. 1985. Сатиры смелый властелин. М., Книга, 268 с.

19. Рассадин С.Б. 2001. Русская литература: От Фонвизина до Бродского. М., Слово, 288 с.

20. Рассадин С.Б. 2008. Умри, Денис, или Неугодный собеседник императрицы (История жизни и творчества Дениса Ивановича Фонвизина). М., Текст, 384 с.

21. Степанов В.П. 1986. Полемика вокруг Д.И. Фонвизина в период создания «Недоросля». XVIII век, 15: 204-229.

22. Томашевский Б.В. 1990. Пушкин. В 2 т. Том 1. Под ред. В.Г. Базанова. М., Худож. лит., 367 с.

23. Фонвизин Д.И. 1959. Письма и дневники. В кн.: Д.И. Фонвизин. Сбр. Соч. Т. 2. М.-Л., Художественная литература, 744 с.

\section{References}

1. Bakhtin M.M. 2000. Formy vremeni i khronotopa v romane: ocherki po istoricheskoi poehtike. [Forms of time and chronotope in the novel: essays on historical poetry]. In: M.M. Bakhtin. Ehpos i roman. [Epic and novel]. SPb., Publ. Azbuka, ABC, 11-193.

2. Belinskii V.G. 1956. Pis'ma: 1829-1840. [Letters: 1829-1840]. Vol. 11. Edited by N.F. Bel'chikova. Complete collection of works. In 13 vol. Publishing House of the Academy of Sciences of the USSR, $718 \mathrm{p}$.

3. Berkov P.N. 1947. Teatr Fonvizina i russkaya kul'tura [Theater of Fonvizin and Russian culture]. In: Russkie klassiki i teatr [Russian classics and theater]. Ed. E. Kuznetsov. M.-L., Publ. Iskusstvo: $7-108$.

4. Blagoy D.D. 1960. Istoriya russkoy literatury KhVIII veka [History of Russian Literature of the Eighteenth Century]. Ed. D.L. Ustyuzhanin. M., Publ. Uchpedgiz, 582 p.

5. Vyazemskii P.A. 1848. Fon-Vizin. Saint Petersburg, Publ. Tip. Dep. vnesh. torg., 468 p.

6. Gukovskiy G.A. 1947. Fonvizin [Fonvizin]. In: Literatura XVIII veka [Literature of the 18th century]. Vol. IV. Istoriya russkoy literatury [History of Russian Literature]. In 10 vol. M.-L., Publ. AN SSSR: $152-200$.

7. Gukovskiy G.A. 1999. Russkaya literatura XVIII veka [Russian Literature of the 18th Century]. M., Publ. Aspekt Press, 453 p.

8. Gornfel'd S.V. 1890-1907. Entsiklopedicheskiy slovar' Brokgauza i Yefrona. In 86 vol. SPb.,

9. Zorin A. 1999. Grigoriy Aleksandrovich Gukovskiy i ego kniga [Grigory Alexandrovich Gukovsky and his book]. In: Gukovskiy G.A. Russkaya literatura XVIII vek [Russian Literature of the 18th Century]. M., Publ. Aspekt Press: 3-11. 
10.Korshunova N.V. 2005. Fonvizin. [Fonvizin]. In: Obshchestvenno-politicheskaya mysl' Rossii KHVIII - nachala KHKH veka. Ehntsiklopediya. Socio-political thought of Russia of the XVIII - early XX century. Encyclopedia. Edited by V.V. Zhuravlev. M., Rossiiskaya politicheskaya ehntsiklopediya (ROSSPEN): 583-584.

11. Kulakova L.I. 1966. Denis Ivanovich Fonvizin [Denis Ivanovich Fonvizin]. L., Publ. Prosveshchenie, $177 \mathrm{p}$.

12. Maydanskiy A.D. 2008. Logika i fenomenologiya vsemirnoy istorii [Logic and Phenomenology of World History]. $\mathrm{N}$ APXH, 5: 146-169.

13. Makogonenko G.M. 1969. Ot Fonvizina do Pushkina. Iz istorii russkogo realizma [From Fonvizin to Pushkin. From the history of Russian realism]. M., Publ. Khudozhestvennaya literatura, 498 p.

14. Marks K. 1959. K kritike politicheskoi ehkonomii. To the criticism of political economy. In: K. Marks, F. Ehngel's. Collected works. Ed. 2. Vol. 13. M., Politizdat, 771 p.

15. Moryakov V.I. 2011. D.I. Fonvizin on France of the last third of the 18th century. Moscow university bulletin. Series 8: History, 3: 52-68 (in Russian).

16. Pigarev K.V. 1954. Tvorchestvo Fonvizina [Creativity of Fonvizin]. M., Publ. AN SSSR, $314 \mathrm{p}$.

17. Rassadin S.B. 1980. Fonvizin [Fonvizin]. M., Publ. Iskusstvo, 288 p.

18. Rassadin S.B. 1985. Satiry smelyy vlastelin [Satyrs are the brave master]. M., Publ. Kniga, $268 \mathrm{p}$.

19. Rassadin S.B. 2001. Russkaya literatura: Ot Fonvizina do Brodskogo [Russian Literature: From Fonvizin to Brodsky]. M., Publ. Slovo, 288 p.

20. Rassadin S.B. 2008. Umri, Denis, ili Neugodnyy sobesednik imperatritsy (Istoriya zhizni i tvorchestva Denisa Ivanovicha Fonvizina) [Die, Denis, or the Empress's Disagreeable Interlocutor (The story of the life and work of Denis Ivanovich Fonvizin)]. M., Publ. Tekst, 384 p.

21. Stepanov V.P. 1986. Polemika vokrug D.I. Fonvizina v period sozdaniya «Nedoroslya» [Controversy around D.I. Fonvizin during the creation of "Nedoroslya"]. XVIII vek, 15: 204-229.

22. Tomashevskii B.V. 1990. Litsei. Peterburg. Lyceum. Petersburg. Book I. Pushkin. In 2 books. Edited by V.G. Bazanova. M., Publ. Art. lit., 367 p.

23. Fonvizin D.I. 1959. Pis'ma i dnevniki. [Letters and diaries]. In: D.I. Fonvizin. Collection of Essays]. Vol. 2 . M.-L., Khudozhestvennaya literatura, 744 p.

Конфликт интересов: о потенциальном конфликте интересов не сообщалось.

Conflict of interest: no potential conflict of interest related to this article was reported.

\section{ИНФОРМАЦИЯ ОБ АВТОРЕ}

Меринов Валерий Юрьевич, кандидат философских наук, доцент, доцент кафедры журналистики института общественных наук и массовых коммуникаций Белгородского государственного национального исследовательского университета, г. Белгород, Россия

\section{INFORMATION ABOUT THE AUTHOR}

Valeriy Y. Merinov, Candidate of Philosophical Sciences, Associate Professor, Associate Professor of the Department of Journalism of the Institute of Social Sciences and Mass Communications, Belgorod National Research University, Belgorod, Russia 